\section{COOPERATION BETWEEN SCHOOL AND COLLEGE}

Standing at the point of contact between the secondary school and the college, the board recognizes as first in order of importance the principle of cooperation between school and college. The board represents a cooperation between the colleges on the one hand and the secondary schools on the other in respect to a matter of vital importance to both. Not only the colleges, but also the secondary schools should have, and do have, a voice both in framing and administering the policies of the board.

\section{UNIFORM REQUIREMENTS}

In the second place, the College Entrance Examination Board does not itself assume power or claim a right to formulate definitions of the requirements for admission to college. Those definitions that have been adopted by the board have been drawn up and recommended by representative bodies of teachers recognized as having authority to speak for the subjects concerned. As a result, the requirements adopted by the board possess the two important characteristics of uniformity and stability. 'They can be altered only when the desirability of change has been approved by a properly representative body of teachers; and any change which is made applies equally to all institutions.

\section{COLLEGE RETAINS ITS INDIVIDUALITY}

In the third place, while the board represents a combined effort on the part of many colleges, it is provided that no college shall surrender its own individuality. Each institution preserves the right to enforce such standards of excellence as it pleases or to make such allowance as it wishes for character and capacity on the part of students applying for admission. The certificate issued by the board states merely that the holder was examined at a stated time and place in specified subjects, and, as the result of such examinations, received the ratings entered on the certificate. Fach college determines for itself what subjects it will require for admission and what minimum rating it will accept as satisfactory.

\section{SUMMARY OF ADVANTAGES}

In conclusion, then, permit me to enumerate the following manifest advantages of the examinations held by the College Entrance Examination Board:

1. They are uniform in subject-matter. An examination in a given subject means exactly the same thing evervwhere in the United States.

2. They are uniformly administered.

3. They are held at many points, to meet the convenience of students, at one and at the same time.

4. They represent the cooperative effort of a group of colleges, no one of which thereby surrenders its individuality.

5. They represent the cooperation of colleges and secondary schools in respect to a matter of vital importance to both.

6. By reason of their uniformity they aid greatly the work of the secondary schools. If a class is studying a certain subject, it is no longer necessary to divide the class into groups according to the particular institutions for which the students are preparing.

7. They tend to effect a marked saving of time, money and effort in administering college admission requirements.

\section{THE ST. LOUIS HOSPITAL}

DOUGLASS W. MONTGOMERY, M. D.

\section{SAN FRANCISCO}

The St. Louis Hospital of Paris is one of the oldest seats of medical learning in the world, and it looks it. Most of the buildings are ancient and, as they lack any of the modern architectural improvements, they must be expensive to run. The food, for instance. is transported long distances in large brass kettles. This must be costly, and, besides, the victuals become cold and flavorless before they reach the patient.

As the old buildings fall out of repair, the economical procedure would be to replace them by new ones. The administration, however, does not seem inclined to pursue this course. A notable exception to this state of affairs, however, is the modern building and complete equipment for treating diseases of the skin in the service of Prof. L. Brocq. This is one of the best plants of its kind $I$ have ever seen, and is run to the best advantage by jts competent chief and his corps of assistants.

The amount of clinical material in the St. Louis Hospital is, however, immense, and the physicians handling it, especially those interested in diseases of the skin, are among the foremost men in the world. It is this material and these men that make the St. Louis Hospital what it is.

One of the most interesting clinies is that of Sabonrand for diseases of the scalp.

Sabouraud is perhaps best known by his introduction of the $x$-rays as a depilatory in the treatment of ringworm of the scalp in children. Previous to this innovation the disease formed a serious problem among the school children in Paris. Now there are so few cases that application has been made to allow those from the neighboring departments to come to the St. Louis Hospital for treatment. Ultimately Sabouraud expects ringworm to be reduced to a few sporadic cases. As he expressed it, this method of treatment will do for ringworm what vaccination has done for small-pox.

The first step in this method is to cut the hair with clippers. The scalp must not be shaved, as that would remove the hairs so closely that they could not be extracted by pincettes, a most important point, as will be seen presently. The $x$-rays are then applied until a full dose is given, as measured by the radiometer of Sabouraud and Noiré. The delicacy of this operation will be dwelt on later. After this the hair becomes loose. and can easily be pulled out. Just here is a matter of importance to be observed. The bald patch caused by exposure to the $x$-rays must be examined with thie minutest care for any small hairs that may still remain in their follicles, as these may contain some of the fungus, and one hair containing viable spores or filaments is sufficient to cause a recurrence of the disease.

After this epilation the whole scalp is rubbed every evening with a salve composed of:

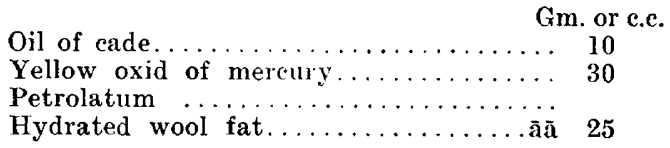

This ointment is allowed to remain over night, and next morning is washed off with soap. Then a spot larger than the diseased area is painted with:

Tincture of $\operatorname{iodin} \ldots \ldots \ldots \ldots \ldots \ldots \ldots$ 
A remarkable feature of this treatment is the complete omission of sulphur as a parasiticide; it is replaced hy tincture of iodin diluted with alcohol.

Tincture of iodin is now a favorite antiseptic in a great many integumentary diseases, and is also frequently used to sterilize the skin in surgery. For instance, in L. Brocq's clinic, in giving an injection of salvarsan, the skin was first painted with tincture of iodin, and then the needle was inserted. The same procellure is adopted in incising a furuncle. In these cases the tincture of iodin is used pure. It is diluted in ringworm. because undiluted it would be too strong to be emploved for several weeks daily, as is necessary in this diacase.

The ointment of tar and yellow precipitate is not an escential part of the treatment, and if it irritates the scalp so as to render its employment distressing, it may be replaced by an oxid of zinc paste $(5-30)$.

The soap may also act as an irritant, and should it do so, an egg shampoo may be substituted, as being more bland.

The absence of the use of sulphur has been mentioned as a peculiarity in this treatment. It may, however, be advantagcously employed in suitable cases. For instance, if a folliculitis supervenes, the following sulphur lotion may be prescribed:

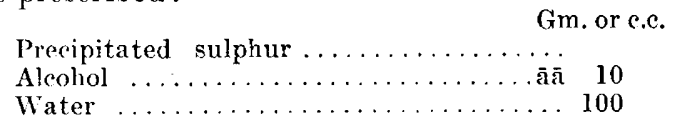

The alcohol is an important constituent of this prescription, as by first triturating the alcohol and sulphur together, and then adding the water, the sulphur is better distributed throughout the lotion, and can be more easily shaken up to form a milk of sulphur.

Frequently an ordinary pyogenic infection is assorinted with ringworm, and then eau d'Alibour, Alibour's lotion. is found to be an excellent remedy. I first became acquainted with the use of this lotion in reading Prof. L. Brocy's treatise on diseases of the skin. It is a fine antiseptic, and one long in use by French physicians. It is estemed so highly, that on my evincing a special interest in it, Dr. H. Noiré, who had charge of the clinic, hat the kindness to demonstrate its mode of preparation.

It is composed of :

\begin{tabular}{|c|c|}
\hline & Gm. or c. \\
\hline $\begin{array}{l}\text { Sulphate of copper. } \\
\text { Sulphate of zinc... }\end{array}$ & .. 2 \\
\hline $\begin{array}{l}\text { Sulphate of zinc..... } \\
\text { Camphorated alcohol }\end{array}$ & · $\begin{array}{r}7 \\
20\end{array}$ \\
\hline Water ..... & to 2000 \\
\hline
\end{tabular}

The sulphate of copper and the sulphate of zinc are first dissolved by trituration with a small quantity of water in a mortar. The camphorated alcohol is also adkled to a few grams of water and filtered and then poured over the above-mentioned solution of the copper and zinc salts. To this enough water is then added to measure up to either 1,000 or $2,000 \mathrm{gm}$., according as a stronger or weaker antiseptic is desired.

In former days saffron was also included in this prescription, and long boiling was necessary in order to extract the coloring matter from it. These were the days when the color of a therapeutic agent was supposed to plav a great part in its efficacy. Ask almost any modern medical man about the doctrine of signatures, and if he does not happen to surmise you may be talking of some question in medical jurisprudence relating to the forging of bank-checks, he will answer by a blank stare. Yet the loctrine of signatures once played a great rôle in the practice of medicine. According to this doctrine it was thought that rhubarb acted beneficially on the liver because of its yellow color, resembling bile. It is needless to say that leaving out the saffron in the eau d'Alibour does not diminish its efficiency. The camphor, however, should not be omitted, as it acts suavely and beneficently on the skin.

The camphor in mass should not be added directly to the water, as it will float and refuse to dissolve, except under long trituration. If, however, it is added as camphorated alcohol, it readily associates with the water.

The eau d'Alibour is an excellent antistreptococcic as well as antistaphylococcic lotion, and may therefore be advantageonsly used in erysipelas and in panaritium.

If a treatment is strikingly efficacious it may also be depended on to have its disadvantages. The $x$-ray treatment for ringworm of the scalp is no exception to this rule. The difficulty of treating ringworm of the scalp by the ordinary methods lies in the thick coating of stout hair in which the fungus lodges. As the affected area is completely denuded of hair by the $x$-ray, the disease then becomes as easy to treat as if on the free surface of the skin. In order to secure this complete denudation, however, a heavy dose of the $x$-rays has to be given-usually about fourteen minutes at $20 \mathrm{~cm}$. The risk of causing an $x$-ray burn is therefore imminent. When the pastilles of Sabouraud, which are placed midway between the target of the tube and the patient's scalp, change color, the current is shut off. These pastilles are made in Germany, England and France, and the delicacy of the operation may be judged by the fact that Noiré drew my attention to the fact that the control tints in the pastilles made in both England and Germany were wrong.

When I spoke to one of the most eminent specialists on diseases of the skin in the St. Louis Hospital of the denudation of the scalp by the $x$-rays, he shook his head and said, "That is a delicate matter." In Sabouraud's clinic they say they never have any unfortunate results with the $x$-ray, but other operators sometimes get permanent baldness. Then there may be burns, but it is not necessary to have a burn to have trouble. In Wickham's Clinic I saw a neyus-like dilatation of the small ressels of the skin that appeared sereral weeks after exposure to $x$-rays, where there had been no burn.

While in London I mentioned to a skin disease specialist, who used the Sabouraud treatment for ringworm of the scalp, what Noiré had told me of the incorrect control tints in the radiometer as made in England, and got the following interesting explanation: A practitioner caused an $x$-ray burn, and the patient sued for damages. The physician in his defense said that he was guided in his dosage by the tints on the radiometer, whereupon the patient entered suit against the manufacturer and won. As a consequence the manufacturer so changed the tints as to conform to a much smaller dose of the $x$-rays. That the dose as indicated is ineffective did not trouble him. In England just now there seems to be a mania for making any one who has any money responsible for anyone who has nothing. That line of conduct has its disadvantages, however, as above shown by the example of the radiometer.

In order to get a just idea of the enormous skin disease material passing through this hospital it is necessary to attend the general admission clinic. Here the patients, stripped to the waist, march in line up to the examining physicians. There is no attempt at history taking; the diagnoses are of the speediest; and the few words relating to treatment are given with equal haste. It is an embarrassment of riches, and amounts to a great evil, as it induces a habit of making snap diacnoses. 
Two parasites play the leading rôles in this procession, the Spirochata pallida, and the itch-mite. If the patient has syphilis, he is asked if he wishes to enter the hospital, and if he has scabies, the physician inquires if he is married or single. If the patient is married, he is advised to include his wife and family in the treatment. The necessary questions and commands are uttered with the automatism of a church service, and the whole affair passes along with cinematographic rapidity.

It is easy, however, to be a critic, especially an adverse critic. Every one should be judged by what he has accomplished, and undoubtedly the French are doing a good day's work in medicine, and especially in diseases of the skin.

It is interesting to watch these long lines of almost naked human beings advancing toward the phrsician, who is to order for one tar, for another mercury, for another resorcin, and for still another sulphur as an amelioration or a cure. In Genesis it is stated man is made of clay. Human beings are, therefore, according to this view, nothing but animated pottery, and on the surface of these stronger or weaker vessels one may see different designs; on one a patchy sealiness indicating psoriasis, and on another papules curiously formed and arranged, spelling out clearly the diagnosis svphilis; in ret another, lichen; and in still another, pediculosis. It must be said that these spots and splaslies of color, and rococo outbuddings are more fantastic than artistic, but their correct interpretation becomes. after a time. as interesting as any game or employment in which the perceptive faculties are actively called into play.

The physicians here are the same as in other parts of the world, in that they do a great deal of good work gratuitously, but in following St. Paul's advice to distribute to the necessity of saints, they find that the comforted saints often exhibit a frail side. $A s$ an instance of this, I ran across a curious industry in the St. Ionis Hospital. A patient would apply for treatment, and receivc the appropriate medicine free of charge. Then he would promptly march off to a drug-store and sell it. Those suffering from srphilis are said to he particularly iniquitous, and the little proto-iodid of mereurr pills are easily disposed of. It mar be objected that these are nnt saints, but in truth ther are, for repentance is of the very essence of sainthood. and fittingly to repent it is necessary first to accumulate a good stock of sin, together with a good admixture of misery. The woll-fed, comfortable sinner, like the king in Hamlet, stops short of complete repentance, and therefore caninot attain the crown of sainthood.. It is to these shattered hulks. dismasted and battered by the storms of lipe that Rabclais dedicates his great book. It was such as these that stirred the sympathies of the greatest Seotchman that ever lived, and inspired him to write the oreat poem. "The Jolly Beggars." Many of the patients in the clinic of the St. Ionis Hospital looked as if they could eat a dinner. and without waiting for the recommendatory preface of a benediction either.

323 Geary Street.

Medical Inspection of Schools.-Medical inspection is becoming a vital part of every modern system of education. To obtain valuable results accurate data are necessary. It is escential that thorough supervision be made by a state medical inspector, who should be a medical man. A state association of medical inspertors should be formed. Permanent efficiency will require skilled workmen. careful arministration and adequate remuneration. W. J. Lamson, in Journal of the Medical Society of Nex Jersey.

\section{THE TEACHING OF VISCERAL ANATOMY, OR ORGANOLOGY}

JERTEMIAH S. FERGUSON, M.S., M.D.

Assistant Professor of Histology, Cornell Cniversity Medical College NEW YORK

Medicine as a science is yet in its infancr; its composite development, its evolution, forms a steadily increasing curve, but each of its component parts form irregular curves with frequent rises, falls and stationary levels, when historically considered. The close of the last century marked the completion of a period of ranid development in surgical science, during which it was, perhaps, eminently desirable that the medical student should view anatomy with exaggerated reference to its surgical importance.

The beginning of the present century offers promise of an equally important development on the side of internal medicine. The former necessity is now superseded by the latter, and for the internist an accurate and extensive familiarity with visceral anatomy is of fundamental importance.

If there was a time when students could be allowed to devote weeks to the careful dissection of an arm or a leg and then for want of time pass cursorily over the abdominal contents and perhaps fail entirely to open the thorax, cranium or spinal canal, that time is past: the demands of the internist in the present generation call not only for careful risceral work in the dissecting-room but for an amplification of that course by such methods as shall result in accurate conceptions of living structure, which in turn can result only from the familiarity obtained through extensive first-hand acquaintance witi, the tissues themselves. It is for the satisfaction of these demands that courses modeled along the lines which I am about to indicate must be uffered to the medical student of to-day.

The form, position and external relations of the organs are best obserred in the "fixed" material of the dissecting-room, and if only recently prepared or carefully preserved tissue is used, the conception in the mind of the student will be well formed. But it is essential that the tissue be perfectly preserved and that the dissection shall be so rapid and careful as to allow no opportunity for excessive evaporation with coincident changes of color, texture and size. Even at its best, proserved dissecting-room material will show considerable changes in color and some hardening of texture. Material which has lain for weeks on the table during the dissection of the limbs and body wall, mnless it hias received the best of care, is not entirely satisfactory for the proper study of the viscera. To obtain the best results from the standpoint of organology a borly freslily prepared by injection should be brought directly from the preparation room, its paries at once opened, as at autopsy, and its riscera carefully survered, as rapidly as is consistent with thoroughness, first for their position and general relations and then for form and structure. Such organs as are not badly altered by disease should then be removed, their connections to paries and to adjacent organs and especially their vascular connections being carefully noted; then their surface marlings are to be carefully observed and their architecture thoroughly studied. Even at the loss of some material the finer details of dissection involving the topographic anatony of the organ will be better pursued on other material.

But even at its best, dissecting-room material only partially fulfils the requirements of an accurate concep- 